\title{
Analysis of Lipid Profile in Subclinical Hypothyroidism at Tertiary Care Hospital-An Observational Study
}

\author{
Mehul Marwadi ${ }^{\oplus 1}$, Kanugir Gosai ${ }^{\oplus 2}$ \\ ${ }^{1}$ Assistant Professor, Department of Medicine, Parul Institute of Medical Sciences and Research, Limda, Waghodiya, Vadodara, Gujarat, India, ${ }^{2}$ Associate Professor, \\ Department of Medicine, Parul Institute of Medical Sciences and Research, Limda, Waghodiya, Vadodara, Gujarat, India.
}

\section{Abstract}

Background : Subclinical hypothyroidism could damage vascular function by suggesting enhance in SVR and arterial rigidity and by changing endothelial purpose and so increasing the danger of atherosclerosis and coronary artery disease. The objective of this study is to analyze the relation amid SCH and serum lipid parameters in this subgroup. Subjects and Methods: Current research was performed for the duration of one year at the Department of Medicine, tertiary care institute of India, in patients diagnosed with Sub Clinical Hypothyroidism. Eighty patients were incorporated in the present study and 80 age- and sex-matched and regularly menstruating healthy controls, which were evaluated for the Thyroid Function test, were randomly recruited from staff and volunteers. T3, T4, and TSH were anticipated by utilizing quantitative hard stage ELISA, whereas TC was estimated with photometric determination according to the CHOD PAP method; TG and HDL were estimated by using the enzymatic colorimetric method. Results: There is a momentous augment in the serum TC stage in group II individuals $161.14 \pm 48.23$ mg/dl when compared to group I $124.35 \pm 9.57 \mathrm{mg} / \mathrm{dl}$, it is also a significant amplify in serum LDL-Cholesterol in group II individuals $97.99 \pm 32.42$ $\mathrm{mg} / \mathrm{dl}$ when compared to group I individuals $63.35 \pm 7.55$. Conclusion: Subclinical hypothyroidism ( $\mathrm{SCH}$ ) is linked with increased serum TC and LDL-C levels. As a result, a prospective association amid subclinical hypothyroidism and atherosclerosis occurs. Larger studies are needed to prove this association in Indian patients.

Keywords: Observational Study, Subclinical Hypothyroidism, Thyroid Function Test, Thyroxine

Corresponding Author: Kanugir Gosai, Associate Professor, Department of Medicine, Parul Institute of Medical Sciences and Research, Limda, Waghodiya, Vadodara, Gujarat, India.

E-mail: kanugir.gosai77663@paruluniversity.ac.in

Received: 21 June 2020

Revised: 02 August 2020

Accepted: 10 August 2020

Published: 30 December 2020

\section{Introduction}

$\mathrm{SCH}$ can be described as an elevated serum thyroidstimulating hormone (TSH) and normal serum total/free thyroxine (T4), triiodothyronine (T3) concentrations linked with little or no signs of hypothyroidism. ${ }^{[1,2]}$ Subclinical hypothyroidism is a lot more frequent than obvious hypothyroidism, ${ }^{[3,4]}$ with a global occurrence of about $7.5 \%$ to $8.5 \%$ in women and $2.8 \%$ to $4.4 \%$ in men. ${ }^{[5]}$ Hypothyroidism can be either primary that is due to the defect in the thyroid gland (or) secondary due to the defect in the pituitary gland. ${ }^{[6]}$ Overt hypothyroidism is associated with dyslipidemia or hence with atherosclerosis and cardiovascular disorders. ${ }^{[7]}$ The co-relation between dyslipidemia and overt hypothyroidism is well established. ${ }^{[7]}$ The symptoms related to $\mathrm{SCH}$ are nonspecific and depend on individual sensitivity to different circulating. ${ }^{[8]}$ Though $\mathrm{SCH}$ can affect various organ systems, the cardiovascular system is the chief objective. In
SCH patients, the cardiac hemodynamic changes reported are diastolic dysfunction, improved systemic vascular resistance (SVR), and abridged systolic function that are comparable to individuals examined in evident hypothyroidism. ${ }^{[9]}$ Moreover, an inconsistent change to atherogenic lipids may also add to cardiovascular risks. ${ }^{[10]}$ Cardiovascular risk in $\mathrm{SCH}$ is controversial, as some of the studies have shown an increase in myocardial infarction and heart failure, whereas others did not find any increase in cardiovascular disease or mortality. ${ }^{[1-13]}$ This discrepancy could be due to differences in study population (age, sex), techniques of assessment of cardiovascular disease, TSH range that defines $\mathrm{SCH}$ and dissimilarity in modifications for recognized risk factors for cardiovascular disease. As SCH is being analyzed more often in adolescent and middle-aged people, there is a need to know the consequence of SCH on cardiovascular menace features in young individuals. Therefore, the purpose of this research is to analyze the relation among $\mathrm{SCH}$ and serum lipid parameters in 
this subgroup.

\section{Subjects and Methods}

This observational study was conducted for the duration of one year at the Department of Medicine, tertiary care institute of India, in subjects diagnosed with Sub Clinical Hypothyroidism [defined as normal T3 or FT3, normal T4 or FT4, and with increased TSH. Subclinical hypothyroid cases and Euthyroid controls aged between 18-60 years of both sexes were included. Patients with a history of Diabetes Mellitus, Coronary Heart Disease, Obesity, Acute disease, \& another disarray that influence Lipid metabolism. Patients taking any drug like Lithium, Antiepileptics-Carbamazepine, phenytoin, Betablockers-propanolol, Carbimazole, Propylthiouracil, Steroids, etc. which affects the thyroid \& lipid metabolism were excluded. Known hypothyroid patients and Patients who were exposed to thyroid hormone therapy (or) Lipid-lowering agents were not incorporated in this research. Informed consent was acquired from all the applicants. 80 patients were included in the present study and 80 age- and sex-matched and regularly menstruating healthy controls, which were evaluated for the Thyroid Function test, were randomly recruited from staff and volunteers. Blood samples were drained at 08:00 h after an during the night fast in a sterile bottle. Serum was separated for the estimation of serum TSH, T3, T4, and total cholesterol (TC), triglyceride (TG), high-density lipoprotein (HDL), low-density lipoprotein (LDL), which were derived from TC and TG, using Friedwald's Formula, Very lowdensity lipoprotein (VLDL) derived from TG. ${ }^{[9,10]} \mathrm{T} 3$, T4, and TSH were estimated by using quantitative hard stage ELISA, whereas TC was estimated with photometric determination according to the CHOD PAP method; TG and HDL were estimated by using the enzymatic colorimetric method.

\section{Statistical Analysis}

The data were analyzed using SPSS version 15. For all tests, confidence level and level of significance were set at $95 \%$ and $5 \%$ respectively.

\section{Results}

In group I persons, the mean serum T3 level was $115.10 \pm$ $28.14 \mathrm{ng} / \mathrm{dl}$. In group II persons, the mean serum T3 level is $107.45 \pm 35.32 \mathrm{ng} / \mathrm{dl}(\mathrm{p}=0.12)$. In group I individuals, the mean serum T4 level is $7.80 \pm 1.22 \mu \mathrm{g} / \mathrm{dl}$. In group II individuals, the mean serum T4 level is $6.65 \pm 1.47 \mu \mathrm{g} / \mathrm{dl}(\mathrm{p}$ $=0.20$ ). The levels of TSH are significantly higher in group II $9.14 \pm 5.87 \mu \mathrm{IU} / \mathrm{ml}$ compared to group I $3.54 \pm 1.12 \mu \mathrm{IU} / \mathrm{ml}$, $\mathrm{p}<0.0001$, which is considered to be statistically significant. There is a significant increase in the serum TC level in group II individuals $161.14 \pm 48.23 \mathrm{mg} / \mathrm{dl}$ when compared to group I $124.35 \pm 9.57 \mathrm{mg} / \mathrm{dl}, \mathrm{p}<0.0001$; this difference is considered to be statistically significant. There is also an important amplify in serum LDL-Cholesterol in group II individuals $97.99 \pm 32.42 \mathrm{mg} / \mathrm{dl}$ when compared to group I individuals $63.35 \pm 7.55, p<0.0001$, which is statistically significant. There is no significant difference in serum HDLCholesterol among group I $(39.64 \pm 6.24 \mathrm{mg} / \mathrm{dl})$ and group II $(35.01 \pm 9.74 \mathrm{mg} / \mathrm{dl}), \mathrm{p}=0.0702$, which is not quite statistically significant. In group I individuals, the mean serum TG is $137.12 \pm 41.32 \mathrm{mg} / \mathrm{dl}$. In group II individuals, the levels are $147.98 \pm 65.87, p=0.24$, which is not statistically significant. A small increase in serum TG level in group II compared to group I may be noted [Table 1].

\section{Discussion}

Overt hypothyroidism is linked with the enlarged danger of cardiovascular disease, qualified to amplified TC and LDLC. Hypercholesterolemia is preferential owing to the hormone arrears and to the diminished movement of the lipoprotein lipase. ${ }^{[14]}$ Numerous researches from the previous twenty years have centered on relations amid SCH and serum lipids, which has lingered moderately unstated. The conflicting outcome had accounted in the text about the relationship among $\mathrm{SCH}$, serum lipids and cardiovascular disease. ${ }^{[15,16]}$ The association between subclinical hypothyroidism and serum lipids remains controversial. ${ }^{[17]}$ In numerous researches, subclinical hypothyroidism was established to be connected with an uneven and rather conflicting increase in TC and in LDL$\mathrm{C}$, elevated plasma oxidized LDL-C levels, and incompatible changes in serum levels of HDL-C. ${ }^{[18-22]}$ unavoidably, the lipid outline is further irregular in persons with serum TSH greater than $10 \mathrm{mIU} / \mathrm{liter}$, and it is more unbalanced in those who smoke. ${ }^{[20,22]}$ The current study showed considerably elevated stages of TG and VLDL in subjects with subclinical hypothyroidism. William J. Hueston et al, ${ }^{[23]}$ had comparable results compare to the current study. No statistically significant association was found among total cholesterol, LDL, HDL and subclinical hypothyroidism in current research. Results are analogous to research performed by William J. Hueston et al. In the current research, TC and LDL-C were considerably increased and non-significantly eminent serum TG levels were seen in group II subjects when compared to group I. There was no significant difference in the levels of HDL-C and VLDL-C in the two groups. These findings connected well with the Colorado thyroid disease incidence study, which showed that TC and LDL-C in SCH were appreciably higher than that in euthyroidism but TG and HDL-C was not significantly dissimilar.

\section{Conclusion}

$\mathrm{SCH}$ is connected with elevated serum TC and LDL-C levels. As a result, there is a probable relationship among subclinical 


\begin{tabular}{|llll}
\hline \multicolumn{2}{|c|}{ Table 1: Comparison of Different Parameters of Thyroid Hormones and Lipid Profiles between Case and Control } \\
\hline Parameter & Group I & Group II & p-value \\
\hline T3 $(\mathrm{ng} / \mathrm{dl})$ & $115.10 \pm 28.14$ & $107.45 \pm 35.32$ & 0.12 \\
T4 $(\mu \mathrm{g} / \mathrm{dl})$ & $7.80 \pm 1.22$ & $6.65 \pm 1.47$ & 0.20 \\
TSH $(\mu \mathrm{IU} / \mathrm{ml})$ & $3.54 \pm 1.12$ & $9.14 \pm 5.87$ & $0.001^{*}$ \\
Total Cholesterol $(\mathrm{mg} / \mathrm{dl})$ & $124.35 \pm 9.57$ & $161.14 \pm 48.23$ & $0.01^{*}$ \\
\hline TG $(\mathrm{mg} / \mathrm{dl})$ & $137.12 \pm 41.32$ & $147.98 \pm 65.87$ & 0.24 \\
\hline LDL $(\mathrm{mg} / \mathrm{dl})$ & $63.35 \pm 7.55$ & $97.99 \pm 32.42$ & $0.05^{*}$ \\
\hline HDL $(\mathrm{mg} / \mathrm{dl})$ & $39.64 \pm 6.24$ & $35.01 \pm 9.74$ & 0.08 \\
VLDL $(\mathrm{mg} / \mathrm{dl})$ & $34.54 \pm 15.38$ & $32.08 \pm 13.21$ & 0.5245 \\
\hline
\end{tabular}

hypothyroidism and atherosclerosis. Superior studies are required to prove this relationship in Indian patients.

\section{References}

1. Ayala AR, Danese MD, Ladenson PW. When to Treat Mild Hypothyroidism. Endocrinol Metab Clin North Am. 2000;29(2):399-415. Available from: https://dx.doi.org/10. 1016/s0889-8529(05)70139-0.

2. Cooper DS. Subclinical hypothyroidism. JAMA. 1987;258(2):246-247. Available from: https://dx.doi.org/ 10.1001/jama.258.2.246.

3. Danese MD, Landenson PW, Meinert CL, Powe NR. Effect of thyroxine therapy on serum lipoproteins in patients with mild thyroid failure: a quantitative review of the literature. J Clin Endocrinol Metab. 2000;85(9):2993-3001. Available from: https://doi.org/10.1210/jcem.85.9.6841.

4. Tunbridge WMG, Evered DC, Hall R, Appleton D, Brewis M, Clark F. The Spectrum of Thyroid Disease in a Community: The Whickham Survey. Clin Endocrinol. 1977;7(6):481-493. Available from: https://dx.doi.org/10.1111/j.1365-2265.1977. tb01340.x.

5. Canaris GJ, Manowitz NR, Mayor G, Ridgway EC. The Colorado Thyroid Disease Prevalence Study. Arch Intern Med. 2000;160(4):526-526. Available from: https://dx.doi.org/10. 1001/archinte.160.4.526.

6. Pucci E, Chiovato L, Pinchera A. Thyroid and lipid metabolism. Int J Obes. 2000;24(S2):S109-S112. Available from: https: //dx.doi.org/10.1038/sj.ijo.0801292.

7. Guntaka M, Hanmayyagari B, Rosaline M, Nagesh V. Lipid profile in subclinical hypothyroidism: A biochemical study from tertiary care hospital. CHRISMED J Health Res. 2014;1(4):266-266. Available from: https://dx.doi.org/10. 4103/2348-3334.143014.

8. Biondi B, Cooper DS. The Clinical Significance of Subclinical Thyroid Dysfunction. Endocr Rev. 2008;29(1):76-131. Available from: https://dx.doi.org/10.1210/er.2006-0043.

9. Caraccio N, Ferrannini E, Monzani F. Lipoprotein Profile in Subclinical Hypothyroidism: Response to Levothyroxine Replacement, a Randomized Placebo-Controlled Study. J Clin Endocrinol Metab. 2002;87(4):1533-1538. Available from: https://dx.doi.org/10.1210/jcem.87.4.8378.
10. Ladenson PW, Wilson MC, Gardin J, Kronmal R, Kuller L, Tracy R. Relationship of subclinical hypothyroidism to cardiovascular risk factors and disease in an elderly population. Thyroid. 1994;4:18-18.

11. Klein I, Ojamaa K. Thyroid Hormone and the Cardiovascular System. N Engl J Med. 2001;344(7):501-509. Available from: https://dx.doi.org/10.1056/nejm200102153440707.

12. Rodondi N, Bauer DC, Cappola AR, Cornuz J, Robbins J, Fried LP, et al. Subclinical Thyroid Dysfunction, Cardiac Function, and the Risk of Heart Failure. J Am Coll. 2008;52(14):11521159. Available from: https://dx.doi.org/10.1016/j.jacc.2008. 07.009.

13. Vanderpump MPJ, Tunbrldge WMG, French JM, Appleton D, Bates D, Clark F, et al. The incidence of thyroid disorders in the community: a twenty-year follow-up of the Whickham Survey. Clin Endocrinol. 1995;43(1):55-68. Available from: https://dx.doi.org/10.1111/j.1365-2265.1995.tb01894.x.

14. Mansourian AR, Ghaemi E, Ahmadi AR, Marjani A, Saifi A, Bakhshandeh. Serum lipid level alterations in subclinical hypothyroid patients in Gorgan (Southeast of Caspian Sea). J Chinese Clin Med. 2008;31(4):206-216.

15. Paoli-Valeri M, Guzman M, Jimenez-Lopez V, Arias-Ferreira A, Briceno-Fernandez M, Arata-Bellabarba G. Perfil lipidico aterogenico enninos con hipotiroidismo subclinico. AP. 2005;62(2):128-162. Available from: https://doi.org/10.1157/ 13071309.

16. Duntas LH, Wartofsky L. Cardiovascular Risk and Subclinical Hypothyroidism: Focus on Lipids and New Emerging Risk Factors. What Is the Evidence? Thyroid. 2007;17(11):10751084. Available from: https://dx.doi.org/10.1089/thy.2007. 0116.

17. Duntas LH. Thyroid Disease and Lipids. Thyroid. 2002;12(4):287-293. Available from: https://dx.doi.org/10. 1089/10507250252949405.

18. Lindeman RD, Schade DS, LaRue A, Romero LJ, Liang $\mathrm{HC}$, Baumgartner RN, et al. Subclinical Hypothyroidism in a Biethnic, Urban Community. J Am Geriatr Soc. 1999;47(6):703-709. Available from: https://dx.doi.org/10. 1111/j.1532-5415.1999.tb01593.x.

19. Bauer DC, Ettinger B, Browner WS. Thyroid Function and Serum Lipids in Older Women: A Population-based Study. Am J Med. 1998;104(6):546-551. Available from: https://dx.doi. org/10.1016/s0002-9343(98)00116-8. 
20. Duntas LH, Mantzou E, Koutras DA. Circulating Levels of Oxidized Low-Density Lipoprotein in Overt and Mild Hypothyroidism. Thyroid. 2002;12(11):1003-1007. Available from: https://dx.doi.org/10.1089/105072502320908349.

21. Pirich C, Müllner M, Sinzinger H. Prevalence and relevance of thyroid dysfunction in 1922 cholesterol screening participants. J Clin Epidemiol. 2000;53(6):623-629. Available from: https: //dx.doi.org/10.1016/s0895-4356(99)00187-0.

22. Miura S, Iitaka M, Yoshimura H, Kitahama S, Fukasawa N, Kawakami Y. Disturbed Lipid Metabolism in Patients with Subclinical Hypothyroidism: Effect of L-Thyroxine Therapy. Intern Med . 1994;33(7):413-417. Available from: https://dx. doi.org/10.2169/internalmedicine.33.413.

23. Hueston WJ. Subclinical Hypothyroidism and the Risk of Hypercholesterolemia. Ann Fam Med. 2004;2(4):351-355. Available from: https://dx.doi.org/10.1370/afm.79.
Copyright: (C) the author(s), 2020. It is an open-access article distributed under the terms of the Creative Commons Attribution License (CC BY 4.0), which permits authors to retain ownership of the copyright for their content, and allow anyone to download, reuse, reprint, modify, distribute and/or copy the content as long as the original authors and source are cited.

How to cite this article: Marwadi M, Gosai K. Analysis of Lipid Profile in Subclinical Hypothyroidism at Tertiary Care HospitalAn Observational Study. Acad. J Med. 2020;3(2):42-45.

DOI: dx.doi.org/10.47008/ajm.2020.3.2.10

Source of Support: Nil, Conflict of Interest: None declared. 